\title{
The Influence of the Implementation of Affection-Based Learning With the Help of Poster Media to Improve Bahasa Indonesia Learning Outcome on Students of Grade V SD Inpres Sikumana 3 Kota Kupang
}

\author{
Muhamad R. Letasado ${ }^{1}$, Julhidayat Muhsam ${ }^{1 *}$ \\ ${ }^{1}$ Universitas Muhammadiyah Kupang, Indonesia \\ Department Of Elementary Teacher Education,Universitas Muhammadiyah Kupang. \\ Jl.K.H. Ahmad Dahlan, Kayu Putih, Kupang City, East Nusa Tenggara \\ *Email: adymaper12@gmail.com
}

\begin{abstract}
This research aims to identify the influence of the implementation of affection-based learning with the help of poster media to improve the learning outcome of Bahasa Indonesia of students of grade V SD inpres Sikumana 3 Kota Kupang. This research used quasi experiment method by applying research design of post-test only control group design. The data of the learning outcome of Bahasa Indonesia was obtained through a test of the subject. The population in this research was 65 students. 33 students were selected as the sample taken using random sampling technique, data collection in this research used objective test method. The data obtained was analyzed using descriptive statistical analysis technique and single line ANAVA. This research result shows that there were influences of the implementation of affective-based learning with the help of poster media to improve the learning outcome of Bahasa Indonesia on students of grade V SD Inpres Sikumana 3 Kota Kupang.
\end{abstract}

Keywords: Affection, Poster Media, Bahasa Indonesia

\section{INTRODUCTION}

Complex activities of human beings are the manifestation of a learning process, but it could not be fully understood. Interaction activities use various of method and strategy between the educators and the students so that they are able to implement the learning activities are the meaning of a learning process [7].

Furthermore, interaction occurred between teachers and students is the manifestation of a learning process that is expected to be able to increase the learning interest of the students. Development or life experiences are able to simply elaborate as a sustainable product of interaction from a learning process (Zuraida, 2015).

Positive or negative effect of one's personality depends on their control over material, this becomes the reason how important affection education at school so that one is able to take the responsibility in life. Optimal affection-based learning is able to provide the opportunity for maximum communication and collaboration to occur. With the occurrence of collaborative in the process of learning means that the learning achievement could be reached through integrated learning process involving students' individual interaction to produce the capitalization of attitude, knowledge, and skills.

Human beings are considered as social beings who could not live alone. Every single activity performed by people must need helps from others. To communicate with other people, one uses language to deliver messages. The language that is common to use by Indonesian people is Bahasa Indonesia. Many underestimate Bahasa Indonesia since it is considered as easy to learn and it has been used in daily lives. However, in fact, Bahasa Indonesia has many rules or regulations either from the aspect of pronunciation or writing. Most people in Indonesia, from kids, teens, and adults have not really understood the rules in using the correct and proper Bahasa Indonesia. Start from there, Indonesian government took an initiative to put Bahasa Indonesia as one of the main subjects taught in all level of education in Indonesia.

The subject of Bahasa Indonesia plays a very important role in learning all subjects because in Bahasa Indonesia, it teaches various skills such as reading, writing, paying attention and speaking. All of those skills are really needed in learning.

Therefore, poster media is one of the alternatives in creating creative learning, description delivering as warning, notification, instruction, or taste delivery conveyed visually. That is revealed by Sabri (in Musfiqon, [8]). Moreover, about poster media aiming to attract the attention by combining visual aspects such as lines and words to be understood shortly [1].

Through the implemented observation, it was 
identified that the material determined by the teachers of SD inpres sikumana 3 grade V kota Kupang was dominated by traditional ways, the learning process was considered to still involve one way direction which eventually cause the students to become passive in classroom. To overcome this learning problem, researchers developed affection-based learning with the help of poster media, so that students have a balanced affective, cognitive, and conative. The advantage of affection-based learning is that students are able to feel the balance between the attitude obtained, to have empathy, to be able to solve problems, creative, to help each other and to be able to maximize their intelligence. Therefore, it needs to be applied so that it could be more energetic, interesting, having visual impression as material comprehensive picture, more efficient and effective.

\section{MATERIAL AND METHOD}

This research is categorized as experimental research. Experimental research is a research activity to control, manipulate and observe research subjects. The experimental design used in this study was the experimental design "Posttest Only Control Group Design". In this experimental design there were two groups selected randomly. One group acts as a control group and the other group acts as an experimental group. The treated group is called the experimental group, while the untreated group is called the control group. Then at a predetermined period of time the experimental group was given treatment. After the treatment was complete, measurements were taken out of the two groups.

The research took place in SD Inpres Sikumana 3 Kota Kupang from February to the first week of March 2020. The population of this research is all students of grade V of SD Inpres Sikumana 3 Kupang Kota in the academic year of 2019/2020. The sample of this research taken using random sampling technique in 2 classrooms. One of the classrooms was designated as experimental class, i.e VA with 33 students and class VB was designated as control class with 32 students. This research used two variable, independent variable and dependent variable. Independent variable in this research is affection-based learning and dependent variable in this research is students' learning outcome of Bahasa Indonesia subject.

The type of this research is quasi experiment with its research design "Post Test Only Control Group Design" shown in table 01.

Table 1. Research Design

\begin{tabular}{|lll|}
\hline $\mathrm{E}$ & $\mathrm{X}$ & $\mathrm{O} 1$ \\
$\mathrm{~K}$ & - & $\mathrm{O} 2$ \\
\hline
\end{tabular}

Remarks:

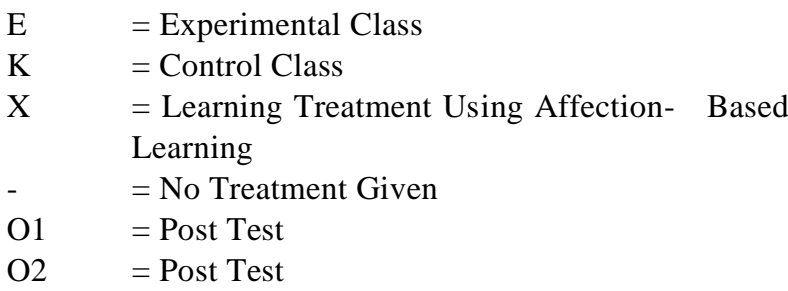

To be able to totally reveal the problem proposed in this research, there were three stages they were preparation stage, implementation stage and the last stage, experiment. The data collected in this research was data about learning outcome of Bahasa Indonesia subject. To measure the study result of his Bahasa Indonesia learning process, test method of multiple choice was used. The data obtained was then descriptively analyzed, by looking for the mean, median, mode, deviation standard and variant from such sample data. Data analysis technique used to test the hypothesis of this research is using a one way variant analysis (ANAVAA).

\section{RESULT AND DISCUSSION}

Overall data recapitulation of Bahasa Indonesia learning outcome of the students i.e. experimental class and control class in Students of $\mathrm{V}$ grade based on the calculation could be presented in this table 2 .

Table 2. Descriptive Statistic Analysis Recapitulation.

\begin{tabular}{|l|c|c|}
\hline \multicolumn{1}{|c|}{ Statistics } & $\begin{array}{c}\text { Experimental } \\
\text { Class }\end{array}$ & $\begin{array}{c}\text { Control } \\
\text { Class }\end{array}$ \\
\hline Mean & 81,08 & 71,88 \\
\hline Median & 75,00 & 70,00 \\
\hline Mode & 85,00 & 70,00 \\
\hline Deviation Standard & 11,588 & 11,897 \\
\hline Variant & 134,280 & 141,532 \\
\hline
\end{tabular}

Table 02 above shows that the average score of Bahasa Indonesia learning outcome of the students in experiment class taught using affection-based learning using poster media tended to have higher score of outcome of Bahasa Indonesia subject compared to students taught using conventional learning method.I

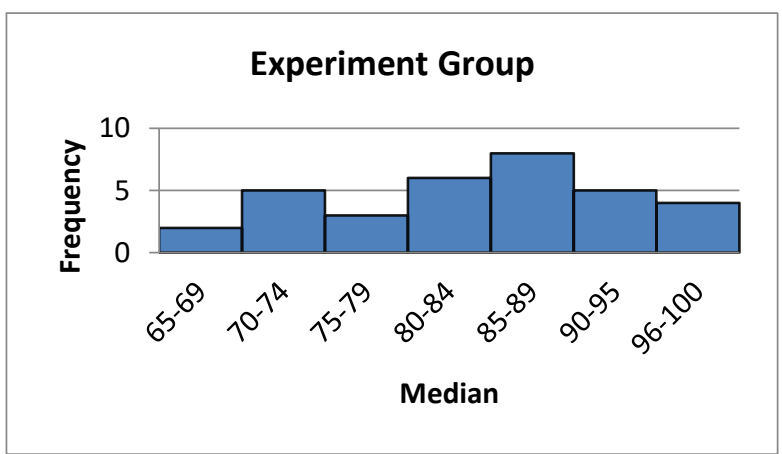

Figure 1. Histogram of Bahasa Indonesia Learning. 
The followings are the score of scientific process skill of the students given the treatment of affective-based learning with the help of poster media was presented in the form of histogram as in Figure 1.

Based on histogram Figure 01, it shows that the data distribution of the test of Bahasa Indonesia of the students from the experimental group make a negative curve. It means that most of the score from experimental class joining the learning process by using affectivebased learning with the help of poster media tends to be higher. Where, it could be seen from the average score of Bahasa Indonesia learning outcome, students from experimental with the result mean of 81,08 , Median 75.00 Mode 85.00, Deviation Standard 11.588, and Variant 134.280, this shows that Bahasa Indonesia learning outcome of the students in experimental class is in the category of very high.

Furthermore, the distribution of frequency of the learning outcome of Bahasa Indonesia of the students treated by conventional learning in the form of histogram in Figure 2.

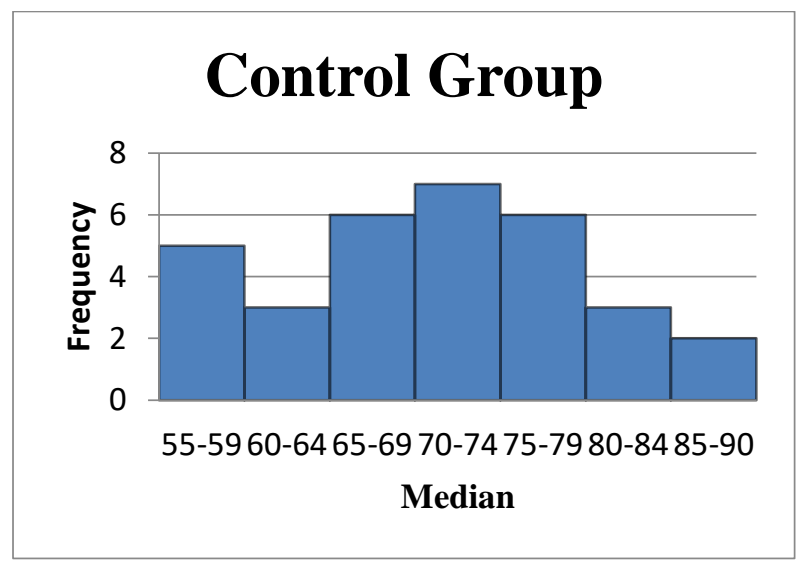

Figure 2. The Histogram of Bahasa Indonesia Learning Outcomes in the Control Class.

Based on the histogram Figure 02 shows that the distribution of Indonesian learning outcomes score data of the control class students formed a positive curve. This means that most of the control class scores that follow learning using conventional learning tend to be low. Where can be seen from the average score of Indonesian language learning outcomes in control class students with Mean 71.88 results, Median 70.00 Mode, 70.00, Standard deviation 11.897, and Variance 141.532. This shows that the score of Indonesian language learning outcomes of control class students is in the category of medium.

Hypothesis testing is performed using the statistical method using ANAVA A with the help of SPSS version 22.0 for windows. The summary of ANAVA A analysis results is shown in table 03 below.
Table 3 Analysis of Anava A

\begin{tabular}{|c|c|c|c|c|c|c|c|}
\hline $\begin{array}{l}\text { Variant } \\
\text { source }\end{array}$ & JK & DK & $\begin{array}{l}\text { RJ } \\
\mathrm{K}\end{array}$ & $\begin{array}{l}\text { Fhi } \\
\text { tun } \\
\text { g }\end{array}$ & sig & $\mathrm{p}$ & $\begin{array}{l}\mathrm{K} \\
\text { et }\end{array}$ \\
\hline $\begin{array}{l}\text { Among } \\
\text { Groups }\end{array}$ & $\begin{array}{l}421,6 \\
84\end{array}$ & 1 & $\begin{array}{l}421 \\
, 68 \\
4\end{array}$ & $\begin{array}{l}3,0 \\
59\end{array}$ & $\begin{array}{l}<0,0 \\
01\end{array}$ & $\begin{array}{l}<0, \\
05\end{array}$ & $\begin{array}{l}\mathbf{S i} \\
\mathbf{g}\end{array}$ \\
\hline $\begin{array}{l}\text { WithinG } \\
\text { roup }\end{array}$ & $\begin{array}{l}8684, \\
479\end{array}$ & 63 & $\begin{array}{l}137 \\
\mathbf{8 4} \\
\mathbf{9}\end{array}$ & & & & \\
\hline Total & $\begin{array}{l}9106, \\
154\end{array}$ & 64 & & & & & \\
\hline
\end{tabular}

Based on the analysis results above, the Fvalue of 3.059 is obtained and sig $=0.001$. This shows sig $\mathrm{p}<0.05$ $(0.001<0.05)$ which means that the null hypothesis which states there is no influence on Indonesian learning outcomes that follow affection-based learning with students who took conventional learning, is "rejected". Thus, it can be concluded that there is an influence on Indonesian language learning outcomes of students who took part in affection-based learning assisted by poster media.

Based on the results of data analysis, which has been done with the help of the SPSS program

version 22.0 for windows it can be seen that learning using affective-based learning assisted by poster media and conventional learning has a different effect on the learning outcomes of Indonesian students. Classes learned using affection-based learning have higher Indonesian language learning outcomes compared to classes taught using conventional learning.

This can be seen from the average score of Indonesian language learning outcomes in both classes. The experimental class has a higher average score, which is 81.08 and is in the very high category, while the control class has a mean score of 71.88 in the medium category. This very significant difference in the learning outcomes of Indonesian students can be explained that affection-based learning provides a great opportunity for students to behave actively and be directly involved in the learning process.

Therefore, the learning process must be interactive, holistic, integrative, scientific, collaborative, and studentcentered. Interactive illustrates that learning objectives are achieved by prioritizing the process of two-way interaction between students and teachers, while holistic is intended that the learning process encourages the formation of a comprehensive and broad mindset by internalizing local and national excellence and wisdom. Regarding Integrative can be achieved through an integrated learning process to meet the overall competency standards of graduates in one program unit through an interdisciplinary and multidisciplinary approach. Scientific can be interpreted 
that the learning process prioritizes the scientific approach so as to create critical thinking based on the value system, norms, and rules of science and uphold the values of religion and nationality. Contextual means that the learning outcomes of graduates are achieved through a learning process that is tailored to the demands of the ability to solve problems in the realm of expertise. Student-centered means the learning process that prioritizes the development of creativity, capacity, personality, and needs of students, as well as developing independence in seeking and finding knowledge.

Learning should be held interactively, inspiringly in a pleasant, exciting, challenging, motivating atmosphere for students to actively participate, and provide sufficient space for initiative, creativity, and independence in accordance with the talents, interests, and physical and psychological development of students. Students as individuals are unique, students have a variety of potential that is not the same between one individual with another even identical twins. This in general can be caused by his life experience which is the influence of the potential they have and the influence of the environment which provides a stimulus for that potential to develop.

The purpose of Indonesian language education according to Chaer and Leonie [4] Education or teaching Indonesian in addition to shaping the personal attitude of Pancasila (with all its conceptual forms) in elementary schools (SD) is so that students can reason, communicate, and convey culture in Indonesian . Indonesian Language Lessons are compulsory subjects for Elementary Schools. Indonesian is a subject that can be studied directly in everyday life, however, many students consider Indonesian lessons to be a difficult subject. Indonesian language learning is basically teaching students about Indonesian language skills that are good and correct according to their goals and functions. According to Atmazaki [2], Indonesian Language lesson aims that students have the ability to communicate effectively and efficiently in accordance with applicable ethics, both orally and in writing, respect and are proud to use Indonesian as the language of unity and country language, understand Indonesian and use it appropriately and creatively for various purposes, using Indonesian to improve intellectual abilities as well as emotional and social maturity, enjoying and utilizing literary works to broaden horizons, character, and increase knowledge and language skills.

Good and correct Indonesian is the Indonesian language used in accordance with prevailing social norms and in accordance with agreed rules of Indonesian language. Arifin [3] said that the use of language properly emphasizes the communicative aspects of language. That means that we must pay attention to our target language. We must pay attention to who we will convey our language to. Therefore, we must not ignore the elements of age, education, religion, social status, social environment, and viewpoints of the target audience.
Based on research findings and strengthened by expert opinion, it can be seen that by using affectionbased learning assisted by poster media can improve the learning outcomes of students' Bahasa Indonesia subject to be better than using conventional learning.

This is supported by previous research carried out by Hildayanti [5] in grade V students of SD Negeri 77 Kanaeng Takalar Regency stated that the results of inferential statistical analysis using the $t$ test formula, it is known that the calculated $t$ value obtained was 10.80 with a frequency of $\mathrm{db}=20-1=19$, at a significant level $=$ 0.05 obtained $\mathrm{t}$ Table $=2.093$ So, $\mathrm{t}$ Count $>\mathrm{t}$ Table or Hypothesis zero (H0) is rejected and alternative Hypothesis (H1) is accepted. This proves that the use of poster media in writing essays on the learning of Bahasa Indonesia has more influence than before using poster media.

\section{CONCLUSION}

Based on the results of hypothesis testing and discussion, it can be concluded that there is a significant influence on Indonesian learning outcomes between groups of students who are taught with affection- based learning assisted by poster media and groups of students who are taught with conventional learning in class $\mathrm{V}$ students of SD Inpres Sikumana 3 Kupang City. The influence can be seen from the average score of Indonesian language learning outcomes of students who take part in affection-based learning assisted by poster media (experimental classes) and students who take conventional learning (control classes).

\section{ACKNOWLEDGMENT}

Our gratitude goes to the Principal and extended family of the Sikumana 3 Inpres Elementary School in Kupang City for allowing this research to be carried out at the school. Thanks also to the Indonesian Ministry of Research, Technology and Higher Education for funding this research through the 2019 Beginner Lecturer research scheme.

\section{REFERENCES}

[1] Anitah. S. 2008. Media Pembelajaran. Surakarta :Panitia Sertifikasi Guru Rayon 13 Surakarta.

[2] Atmazaki. 2013. Mengungkap Masa Depan: Inovasi Pembelajaran Bahasa Indonesia dalam Konteks Pengembangan Karakter Cerdas. Makalah Padan: UNP.

[3] Arifin, Z. 2008. Kaidah bahasa Indonesia. Jakarta: Gunung Agung.

[4] Chaer, A. dan Leonie, A. 2004. Sosiolinguistik. Jakarta: Rineka Cipta.

[5] Hildayanti, dkk. 2018. Pengaruh penggunaan 
media poster dalam menulis karangan narasi terhadap hasil belajar siswa pada mata pelajaran Bahasa indonesia kelas v sd negeri 77 kanaeng kabupaten takalar. Jurnal Kajian Pendidikan Dasar Volume 3. Nomor 2.

[6] Priyatni, Endah Tri. 2014. Desain Pembelajaran Bahasa Indonesia dalam Kurikulum 2013. Jakarta: Bumi Aksara.

[7] Sugihartono. dkk. 2013. Psikologi Pendidikan. Yogyakarta: UNY Press.

[8] Musfiqon. 2012. Pengembangan Media Belajar Dan Sumber Belajar. Jakarta : Prestasi Pustakakarya. 